BJMG 14/2 (2011) 7-12

10.2478/v10034-011-0041-0

COMMENTARY

\title{
STEM CELLS: A PERSONAL PERSPECTIVE
}

Wong $\mathrm{SC}^{1 *}$

*Corresponding Author: Shiu C. Wong, Stem Cell Link, Hong Lok Building, Block M, 1st Floor, 96 Chik Fuk Street, Tai Wai, N.T., Hong Kong, People's Republic of China; Tel.: +852-677-22933; E-mail: scwong555@, gmail.com

\section{DEDICATION}

This Commentary is dedicated to Professor Dr. Georgi D. Efremov, my mentor and my friend, to whom I am indebted for his continued support and advice throughout my professional career.

\section{COMMENTARY}

This is a personal account of my observation of events associated with stem cells in recent years during my stays in Singapore, Malaysia, Canada, Hong Kong and China. It is based on my notes on the news about stem cells from reports broadcast on television, newspapers, magazines and medical journals. It is my perception that the current large amount of news on the developments and applications of stem cells may be confusing to the general public, and that better government regulations on the 'businesses' of stem cells are urgently needed. I will start with a few personal matters and then proceed to the subject proper.

My earlier professional interest was in hemoglobinopathies, during my studies in the late Regents' Professor Dr. Titus H.J. Huisman's Protein Chemistry Laboratory and Comprehensive Sickle Cell Center at

Stem Cell Link, Tai Wai, N.T, Hong Kong, SAR, People's Republic of China the Medical College of Georgia in Augusta, GA, USA. In 2003, my interest turned to 'stem cells' on my appointment as Scientific Director of StemLife, which, at that time, was the only cord blood cryo-preservation bank in Malaysia, with headquarters in Kuala Lumpur and a laboratory in Cyberjaya. While there, I had regular Saturday-open-house, so that potential clients, i.e., pregnant women and their husbands, could learn fully the logistics involved in cord blood banking and view the functioning laboratory through a glass partition. Back then, StemLife was storing close to 100 umbilical cord blood a month.

In 2004, I was involved in the successful use of the umbilical cord blood from a newborn baby boy to save his elder sister from the tragic effects of leukemia. The parents were of Chinese-Malaysian ethnicity in their 30's. Their first child, born the previous year, was a baby girl named Angel, who was diagnosed as having leukemia a few months after birth and was assessed to have less than $10 \%$ chance of survival by her attending physicians. A younger brother, named Sam, was born in April 2004, and when tested was found to be a perfect HLA-match with Angel. Two months later, his cord blood stem cells, which had been stored at the StemLife Cord Blood Bank in Cyberjaya, were retrieved, transported to Kuala Lumpur and transplanted into the 14-month-old Angel at the Kuala Lumpur General Hospital. "After the transplant in 2004/ June, Angel gained her health in months to become the 


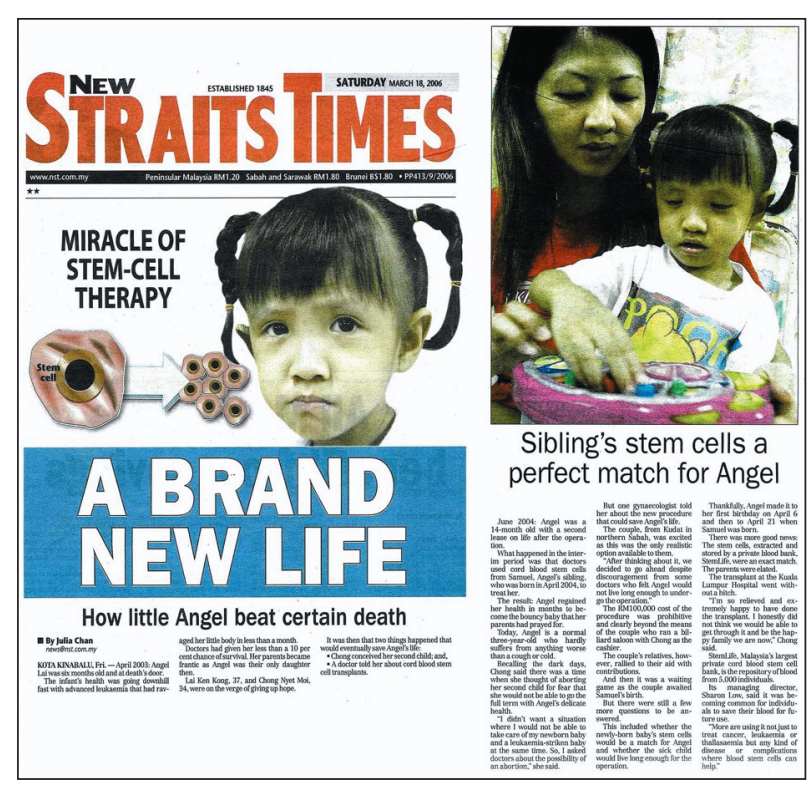

bouncy baby that her parents had prayed for. Today, Angel is a normal three-year-old who hardly suffers from anything worse than a cough or cold." [1].

In September 2008, while in Vancouver, British Columbia, Canada, I saw on television that an American mother with a sick baby daughter and an older son were denied a flight to China for stem cell therapy, because the Vancouver Airport Authority thought that the baby girl was too sick to travel. However, a few days later, this family was allowed to travel to China. This started me to thinking that there must be other clients/ patients who may need professional consultation and assistance in such matters, and, in June 2009, I started Stem Cell Link in Hong Kong (www.stemcelllink. com), specifically to address the concerns and problems of patients seeking stem cell therapy.

In 1963, Andy J. Becker, Ernest A. McCulloch and James E. Till discovered stem cells [2]. Since then, developments in the field have resulted in the establishment of umbilical cord blood stem cell cryo-preservation banks (Cord Blood Banks), adult peripheral blood stem cell cryo-preservation banks (PBSC Banks) and Cellular Therapy Centers worldwide. Because of the widespread information on stem cells, lay people have become impressed by the possible impact and potential benefit of stem cells.

Before the announcement of the 2010 Nobel Prize for Medicine or Physiology, the September 21, 2010 issue of The Scientist reported that "Ernest McCulloch and James Till, both senior scientists at the Ontario Cancer Institute, and Shinya Yamanaka, Kyoto University and University of California, San Francisco, stem cell researchers, for the discovery of stem cells and the development of induced pluripotent stem cells," were possible winners [3]. However, 1 month later, the 2010 Nobel Prize for Medicine or Physiology was awarded to Robert Geoffrey Edwards, for his pioneer work in human IVF (in vitro fertilization) that resulted in the birth of Louise Brown on July 25, 1978 [4].

In the same issue of The Scientist (October 4, 2010) that reported the Nobel prize winner, the question "Is Nobel a nod for ESC (embryonic stem cell) work?" was posed by Alison McCook, who drew "parallels' between IVF and stem cells [5]. Work on IVF had started more than 3 decades ago and had to run the gauntlet of ethical, moral and religious groups, especially with regard to its clinical applications. At one point, the British Medical Research Council had cut the funding for IVF, citing ethical concerns over the project. Similarly, since their discovery in 1963, stem cells have echoed all the same ethical, moral and religious issues. Making the issues even more complicated in recent years have been legal and political arguments on embryonic stem cell research, its funding and its clinical applications in treatment of diseases.

These issues and arguments have had significant consequences in the US in the past decade, where former US President George W. Bush imposed a ban on federal funding for embryonic stem cell research in 2001 [6]. To the great joy of many stem cell researchers, President Obama lifted the ban on stem cell research and signed an Executive Order on March 9, 2009, which stipulated: "We will lift the ban on federal funding for promising embryonic stem cell research. We will also vigorously support scientists who pursue this research. And we will aim for America to lead the world in the discoveries it one day may yield." [7]. A few months later, The Scientist reported: "27 more hESC (human embryonic stem cell) lines approved" by the National Institute of Health (NIH) Director, Francis Collins, making a total of 40 new lines of hESC eligible for federal research funding [8]. However, only 1 year later, new legal proceedings challenging the federal funding of ESC research appeared. In August 2010, federal funding was barred by a District of Columbia judge, but the ban was later lifted by an appeal court. However, this saga continues [9]. It was depicted as the "America's Stem Cell mess" in a recent article in The Scientist, and another titled "Whiplash for stem cell researchers" in Science [10,11].

In spite of the American situation, two new Federal Drug Administration (FDA)-approved clinical tri- 
als were initiated towards the end of 2010. The Geron Corporation in Menlo Park, CA, USA, announced on October 11, 2010 that the first patient with a spinal cord injury had been treated with stem cells at the Shepherd Center in Atlanta, GA, USA [12]. One month later, the Massachusetts-based Advanced Cell Technology (ACT) in Marlborough, MA, USA, also received approval from the FDA to use hESCs to treat patients with Stargardt's macular dystrophy (SMD). According to Robert Lanza, ACT's chief medical officer, "We can generate a virtually unlimited supply of healthy retinal pigment epithelium (RPE) cells, which are the first cells to die off in SMD and other forms of macular degeneration." [13]. At the same time, there was news from the UK on first stem cell therapy for stroke patients [14].

Other clinical uses of stem cells have also been making news. Doctors at the University of Utah have been testing stem cell spray to heal burns, and suggest that synthetic skin derived from a person's own cells may be a reality within 5 years [15]. Moreover, cardiomyocytes from iPSC (induced pluripotent stem cells) are being produced by the Wisconsin-based Cellular Dynamics International in Madison, WI, USA, and these heart muscle cells are available at US $\$ 1,500$ for 1.5 million cells [16]. In connection with iPSC, the contribution of Shinya Yamanaka was acknowledged in the November 27, 2010 Los Angeles Times: "Perhaps no scientist has had a greater impact on stem cell research than Dr. Shinya Yamanaka. His 2006 discovery of induced pluripotent stem cells, or iPS cells, paves the way for pursuing regenerative medicine therapies without the need to destroy embryos." [17]. Within 4 years after their discovery, the use of iPSC has resulted in the production of three generations of live mice [18]. Meanwhile, more information on iPSC is being reported, and one can expect that more will be forthcoming in the near future [19,20].

Such positive publicity on stem cells has given hope and expectation to those who are sick. Television also had its share of news and advertisement on the use of stem cells. Early in 2010, the American weekly TV investigative program 60 Minutes reported the use of stem cells to build tissue-scaffolds that could eventually lead to the generation of complete human organs. This was followed by another 60 Minutes report on the successful use of stem cells to regenerate leg muscles in severely injured American soldiers at the Walter Reed Army Medical Center in Washington, DC, USA.
Meanwhile, certain cosmetic companies are claiming the association of their 'beauty' products with 'stem cell technology' in their TV commercials.

Nevertheless, in the midst of its positive reports on potential uses of stem cells, 60 Minutes had some bad news as well. In a story broadcast in April 2010, Scott Pelley of 60 Minutes exposed a 'doctor' in California and his partner-in-crime, who were offering stem cell treatment, to be performed in Mexico, to patients with amyotrophic lateral sclerosis (ALS) for US $\$ 125,000$. In September 2010, a Dutch-trained doctor, with medical practices in London and Rotterdam, was banned from practice in the UK, after he was found to have made "unsubstantiated and exaggerated claims to patients suffering from degenerative and devastating illnesses, and to charge them thousands of pounds for unproven stem cell treatments" [21,22]. Meanwhile, it took 2 years after the August 2008 death of an 18-month-old child with cerebral palsy, who had received stem cell injection in a private hospital in Dusseldorf, Germany, that the question "why the Government had not reacted more quickly, while the doctor was under criminal investigation for the death" was raised in the German Parliament in October 2010 [23].

On the other hands, these negative reports on unprofessional conducts of a few individuals should not hinder one's appreciation of the potential clinical applications of stem cells in the emerging field of Regenerative Medicine. More than 20 years ago, Dr. H.E. Broxmeyer (Indiana University School of Medicine, Indianapolis, IN, USA) started the first US Umbilical Cord Blood Bank, and Dr. E. Gluckman (Hôpital Saint-Louis, Paris, France) performed the first umbilical cord blood stem cell transplant to treat a patient with Fanconi's Anemia [24,25]. A cord blood bank resembles a commercial bank where the clients and/ or parents rent a safety deposit box held at a temperature of $-196^{\circ} \mathrm{C}$ to keep safe the umbilical cord blood of their newborn for future use. While kept in liquid nitrogen tanks that are maintained at a constant temperature of $-196^{\circ} \mathrm{C}$ with a continued supply of liquid nitrogen, the cryo-preserved stem cells are viable for years to come [26]. Now, umbilical cord blood banks and adult peripheral blood banks are to be found around the world, and thousands of cord blood transplants are being performed each year [27].

Although some new cord blood banks may have resorted to automation and robots in their operation, most banks still use manual procedures to harvest, 
cryo-preserve, track and retrieve the stem cells kept in their facilities. Like other medical laboratories, quality assurance of the laboratory procedures in a cord blood bank can be achieved via accreditation by a professional agency. The College of American Pathologists (CAP) has a long history of accrediting medical laboratories around the world on a voluntary subscription basis [http://www.cap.org]. Its checklists are gold standards for the on-site inspection before accreditation is granted. Similarly, the Foundation for the Accreditation of Cellular Therapy (FACT) also has accreditation programs, which are subscribed by cord blood banks in Canada, USA, UK, The Netherlands, France, Germany, Italy, Spain, Greece, Belgium, Australia, Taiwan and Singapore, as well as by cellular therapy centers in Canada, USA and UK [http://www.factwebsite.org].

There may now be about 200 public or private clinics offering stem cell treatments around the world. Government regulations and oversight, albeit slow, are being gradually implemented, especially after exposure to the public of unprofessional conducts and after media reports of tragic incidents. For example, Germany has tightened and revised laws to regulate treatments using adult stem cells [28]. In The Netherlands, the Dutch Healthcare Inspectorate has been keeping a close watch on clinics offering stem cell treatments to patients [29]. Back in 2007, The Netherlands already had laws that banned "private stem cell therapy for conditions such as amyotrophic lateral sclerosis and multiple sclerosis" [30]. The Health Department in China established laws and regulations on cord blood banking as far back in 1999 and revises them continually [31].

However, the existence of such external accreditation agencies to ensure high professional standards as well as government laws and health inspectorates to oversee the operations of cord blood banks and stem cell therapy centers, does not seem to be totally effective in controlling fraudulent claims and misrepresentations of stem cells. The problem is that implementation and enforcement of these laws and regulations are difficult worldwide. The January 2010 issue of The Economist has highlighted such a problem in China, while acknowledging that the stem cell work in China is 'world-class' and government regulations are in place [32].

New discoveries in the rapidly developing field of Regenerative Medicine are being reported frequently. Clinical applications and therapeutic uses of stem cells are being tried and carried out with promising results.
Because of the high degree of media attention to, and publicity on, stem cells, the public should be aware that unscrupulous opportunists do prey on seriously ill patients and their loved ones by exaggerating the potential (but unproven) applications of these cells and that some producers of cosmetics purposely use the term 'stem cell technology' in their marketing materials.

I have highlighted the amazing discoveries in stem cells and the immense possibilities in Regenerative Medicine for the future practice of medicine. In view of the great potential and promise of human stem cells and in order to protect the public from falling prey to unscrupulous individuals and business operators, I would like to reiterate that clear and strict government laws and regulations must be put in place for licence and medical/business operation requirements. Moreover, an independent stem cell inspectorate needs to be established and empowered with the mandate and legal authority to: a) monitor and enforce total 'compliance' with the government laws and regulations, and b) charge and prosecute any 'non-compliance' to the fullest extent of the law. With these mandates in place, I look forward to hearing more exciting news about stem cells.

\section{ACKNOWLEDGMENTS}

The author would like to thank Ms. Sharon Low of StemLife in Malaysia for [1], Police Chief Inspector Addy Chu (Ret.) of Stem Cell Link in Hong Kong for [31], Professor James Russell, Director, Alberta Blood \& Marrow Transplant Program, Tom Baker Cancer Centre, Calgary, Canada, and Professor Man-chiu Poon of Calgary, Canada for the information on FACT and Professor Frank Vella of Saskatoon, Canada for his critical review of the manuscript.

\section{REFERENCES}

1. Miracle of stem-cell therapy. A brand new life. How little Angel beat certain death. New Straits Times, Saturday, March 18, 2006 (http://www.nst.com.my).

2. Becker AJ, McCulloch EA, Till JE. Cytological demonstration of the clonal nature of spleen colonies derived from transplanted mouse marrow cells. Nature. 1963; 197(4866): 452-454.

3. Grant B. Nobel hopefuls by the number. The Scientist. 2010; September 21. [www.the-scientist.com/blog/ display/57694/] 
4. Schipani, V. IVF pioneer earns Nobel. The Scientist. 2010; October 4. [http://www.the-scientist.com/news/ display/57734/].

5. McCook A. Is Nobel a nod for ESC work? The Scientist. 2010; October 4. [http://blog.the-scientist.com/ 2010/10/4/is-nobel-a-nod-to-esc-work/].

6. Marwick C. President Bush sidesteps critics in stem cell debate. Br Med J. 2001; 323(7309): 357.

7. Tanne JH. Obama reverses US federal ban on funding stem cell research. Br Med J. 2009; 338(7695): 618.

8. Akst J. 27 more hESC approved. The Scientist. 2009; December 15. [www.the-scientist.com/blog/display/ 56219/].

9. Vogel G, Couzin-Franket J. With stem cells in court, a history primer. Science. 2010; 329(5998): 1450-1451.

10. Johnston J. America's stem cell mess. The Scientist. 2010; 24(10): 33.

11. Kaiser J. Breakthrough of the year. Whiplash for stem cell researchers. Science. 2010; 330(6011): 1609.

12. Mayor S. First patient enters trial to test safety of stem cells in spinal injury. Br Med J. 2010; 341(7777): 800.

13. Fox M. Second U.S. company gets stem cell go-ahead. Reuters 2010; November 22. [http://www.reuters. com/ article/2010/11/22/us-stemcells-blindness-sb-idUSTRE6AL0QT20101122].

14. Wise J. First stroke patient is recruited to take part in "milestone" UK trial of stem cell therapy. Br Med J. 2010; 341(7782): 1067.

15. Yeates E. University of Utah doctors testing stem cell spray to heal burns. Deseret News, Salt Lake City. 2010; November 26. [http://www.deseretnews.com/ article/ 700086029/U-of-U-doctors-testing-stem-cellspray-to-heal-burns.html/].

16. Vogel G. Stem cells for sale. Science. 2010; 330 (6008): 1173.

17. Takahashi K, Yamanaka S. Induction of pluripotent stem cells from mouse embryonic and adult fibroblast cultures by defined factors. Cell. 2006; 126(4): 663-676.

18. Zhao XY, Li W, Lv Z, Liu L, Tong M, Hai T, Hao J, Guo CL, Ma QW, Wang L, Zeng F, Zhou Q. iPS cells produce viable mice through tetraploid complementation. Nature. 2009; 461(7260): 86-90.

19. Scudellari M. The iPSC-ESC gap. The Scientist. 2010; February 2. [www.the-scientist.com/news/display/ 57971/].

20. Lister R, Pelizzola M, Kida YS, Hawkins RD, Nery JR, Hon G, Antosiewicz-Bourget J, O’Malley R, Castanon
R, Klugman S, Downes M, Yu R, Stewart R, Ben R, Thomson JA, Evans RM, Ecker JR. Hotspots of aberrant epigenomic reprogramming in human induced pluripotent stem cells. Nature. 2011; 471(7336): 68-73.

21. Dyer C. Stem cell doctor exploited desperate patients, GMC finds. Br Med J. 2010; 341(7773): 576.

22. Dyer C. Stem cell therapy doctor struck off by the GMC. Br Med J. 2010; 341(7776): 749.

23. Tuffs A. Stem cell treatment in Germany is under scrutiny after death of 18 month old child. Br Med J. 2010; 341(7780): 960.

24. Broxmeyer HE, Douglas GW, Hangoc G, Cooper S, Bard J, English D, Arny M, Thomas L, Boyse EA. Human umbilical cord blood as a potential source of transplantable hematopoietic stem/progenitor cells. Proc Natl Acad Sci USA. 1989; 86(10): 3828-3832.

25. Gluckman E, Broxmeyer HE, Auerbach AD, Friedman HS, Douglas GW, Deveragie A, Esperou H, Thierry D, Socie G, Lehn P. Hematopoietic reconstitution in a patient with Fanconi's anemia by means of umbilical-cord blood from an HLA-identical sibling. N Engl J Med. 1989; 321(17): 1174-1178.

26. Broxmeyer HE, Lee MR, Hangoc G, Cooper S, Prasain N, Kim YJ, Mallett C, Ye ZH, Witting S, Cornetta K, Cheng LH, Yoder MC. Hematopoietic stem/progenitor cells, generation of induced pluripotent stem cells, and isolation of endothelial progenitors from 2123.5 year cryopreserved cord blood. Blood. 2011; 117(18):4773-4777.

27. Brunstein CG, Gutman JA, Weisdorf DJ, Woolfrey AE, Defor TE, Gooley TA, Verneris MR, Appelbaum FR, Wagner JE, Delaney C. Allogeneic hematopoietic stem cell transplant for hematologic malignancy: relative risks and benefits of double umbilical cord blood. Blood. 2010; 116(22): 4693-4699.

28. Stafford N. Germany tightens law on stem cell treatments. Br Med J. 2009; 339: b2967.

29. Sheldon T. Dutch clinic is ordered to stop giving stem cell therapy. Br Med J. 2006; 333(7572): 770.

30. Sheldon T. Holland bans private stem cell therapy. $\mathrm{Br}$ Med J. 2007; 334(7583): 12.

31. [http://law.lawtime.cn/d623776628870.html], [http:// law.lawtime.cn/d328408333502.html], [http://law. lawtime.cn/d674375679469.html].

32. Editor. Stem cells in China. Wild East or Scientific Feast. The Economist. 2010; 394(8665): 73. 
